Jadila: Journal of Develomment and Innovation in Language and Literature Education

Publisher: Yayasan Karinosseff Muda Indonesia
Volume 1 Number 12020

Page33-43

\title{
Improving the Students' Ability In Writing Recount Text Through Collaborative Task Writing on Facebook
}

\author{
Fuji Astuti \\ Universitas Galuh Ciamis \\ fuji-astuti@gmail.com \\ Rd. Bunga Febriani \\ Universitas Galuh Ciamis \\ bunga f@gmail.com \\ Andi Rustandi \\ Universitas Galuh Ciamis \\ andi_r@yahoo.co.id \\ Corresponding author: fuji-astuti@gmail.com
}

\begin{abstract}
This study focused on improving the students' ability in writing recount text through collaborative task writing on Facebook. It was aimed at finding out how the teacher improves the students' ability in writing recount text through collaborative writing on Facebook and figuring out the teacher and the students' perceptions on the use of collaborative writing on Facebook in teaching and learning writing of recount text. This case study was conducted to the English teacher and 20 students at the tenth grade of a Senior High School in Kawali. Three instruments covering the observation, the interview, and the questionnaire were chosen to gain the data. The conversational analysis and the statistical techniques were used to analyze the data. The findings showed that the teacher improved the students' ability in writing recount text through collaborative task writing on Facebook. The process of using collaborative writing on Facebook in teaching writing of recount text was implemented in ten steps. The findings also showed that the use of collaborative writing technique on Facebook was beneficial for the teacher in teaching writing of recount text. The findings also showed that the students perceive positively on the use of collaborative task writing on Facebook in teaching and learning writing of recount text. It was concluded that the use of collaborative task writing on Facebook brings some benefits for the teacher and the students in teaching and learning writing of recount text. Therefore, the English teachers were suggested to encourage the students to implement collaborative writing on Facebook in teaching writing of recount text. Meanwhile, the students were also suggested to solve problems in learning writing of recount text by implementing collaboration writing technique on Facebook. In addition, the other researchers can use the result of this research in carrying out further studies.
\end{abstract}

Keywords: writing, recount text, collaborative task writing, facebook

\section{A. Introduction}

Writing is one of the indispensable things in studying English. It is the ability not only to put ideas from mind to paper but also to generate more meaning and make ideas clear. In line with this, writing is seen as a non-linear, exploratory, and generative process whereby writers discover and reformulate their ideas as they attempt to approximate meaning into a paper (Manchón, 2011; Abadikhah \& Yasami, 2013). Therefore, writing seems to be the most demanding skill and the fundamental basis of other language skills for EFL students to master 
(Marleni, 2020; Rahmawati, et al., 2020). Writing skill must be supported by reading skill because by reading a a lot, student could write their ideas (Sofyan, et al. 2019; Dhillon, et al., 2020; Martina, et al., 2020) . Likewise, English writing skill is the fundamental basis of other linguistic skills in speaking, listening, and reading ( $\mathrm{Li}, 2013$, p. 1). In short, writing is the fundamental basis and inseparable part because if the writer wants to master speaking, listening, and reading skill, he/she should writing skill at first.

Students at Senior High School level are expected to be able to write various kinds of genre texts which one of those texts is recount text. It is a kind of texts that retells the writers' activities or experiences in the past. Knapp and Watkins (2005, p. 223) define that "recounts are the simplest text type in this genre which are sequential texts that do little more than sequence a series of events." In short, recount text is a kind of texts which retells the writers' activities or experiences in the past in logical sequence in which the purpose is to entertain the readers. It is expected that the students are able to improve their ability in writing recount text.

However, the writer found that the students faced some difficulties in writing recount text such as difficulties in understanding its structures. Besides, they also faced difficulties in using appropriate tenses of recount text. In addition, they faced difficulties in developing the story of the recount text. Likewise, differences in the language structures, the manner of expressing thoughts, writing styles, and other culturally varying factors greatly affect the writing of foreign language learners (Ahmed, 2016, p. 932). As a result, they often get stuck in the middle of their writing. Likewise, writing is also a difficult skill to improve in a short period of time.

This research focuses on the use of collaborative writing on social media of Facebook. It is an example of an online social networking site which allows friends and families to share information and stay connected with one another. The penetration of information technology, especially in social media in Indonesia is very high, especially in the use of Facebook. From the distribution of age, it appears that most Facebook users are school students. Several social media tools such as MySpace, Facebook and Twitter are tools that could be used for educational purposes (Al-Rahmi, 2017, p. 527). Furthermore, the writer focuses on Facebook because it is mostly used by the students and it is able to be used for collaborative writing in teaching writing of recount text.

Recently, there has been a lot of discussion about the integration of collaborative writing on Facebook in language classrooms, for examples, previous studies conducted by Ananthan and Said (2019), Bailey and Judd (2018), and Mahmud and Wong (2018). Regarding the previous studies described, it is obvious that collaborative writing on Facebook is effective in improving students' writing skill, interest, and motivation. This research has the similarities with those three previous studies because it investigated the use of collaborative writing on Facebook in teaching and learning writing.

However, their studies were focused on ESL students' apprehension towards writing, second language (L2) writing performance, and peer assessment's integration for an English Critical and Creative Writing class. Conversely, it is focused on improving the students' ability in writing recount text through collaborative writing on Facebook.

Based on the background of the study, the research questions that the writer formulates are as follows: (1) How does the teacher improve the students' ability in writing recount text through collaborative writing on Facebook?; (2) How does the teacher perceive the use of collaborative writing on Facebook in teaching and learning writing of recount text?; and (3) How do the students perceive the use of collaborative writing on Facebook in teaching and 
learning writing of recount text? Meanwhile, the purposes of this research are: (1) To find out how the teacher improves the students' ability in writing recount text through collaborative writing on Facebook. (2) To figure out the teacher's perceptions on the use of collaborative writing on Facebook in teaching and learning writing of recount text. (3) To figure out the students' perceptions on the use of collaborative writing on Facebook in teaching and learning writing of recount text.

\section{B. Research Methodology}

This research was conducted to the English teacher and the students at the tenth grade of a Senior High School in Ciamis, especially Kawali district. A qualitative method was used as a method in this research. In this case, qualitative research methods were observed and recorded by the researcher which comes from various sorts of data, and the methods used to collect them (oral and written language practices, interviews, documents, and observations (Wei \& Moyer, 2008, p. 23). Relevant to the purposes and research questions, a case study design was used in this research. In this case, case studies are usually concerned with the individual, not with the general patterns of a population (Wei \& Moyer, 2008, p. 98). The writer took 20 students from class XI-IPS 1 and the English teacher at the tenth grade of a Senior High School in Kawali as the sample of the research.

To collect the data, the writer did the following research procedures. First, the writer constructed the research instruments consisting of the observation, the interview, and the questionnaires. In conducting observation, the writer observed three sessions of the teaching and learning activity in the classroom by videotaping. It was carried out on 8th, 10th, and 15 th of January, 2020. It was conducted by using blended learning. The first and the third meeting were conducted in the inside of the classroom. Meanwhile the second meeting was conducted in the outside of the classroom. In observing the participants, the writer just observed and did not involve directly in the activity by recording all the activities in the classroom.

The interview was also conducted too the teacher which was used to support the result of the observation. Furthermore, there were five (5) questions in the interview which were adapted from Ibrahim, et al. (2018, pp. 64-65). It was carried out on 15th of January, 2020. Furthermore, the writer acted as the interviewer and the teacher acted as the interviewee. At the same time, all the interview conversation was recorded by the writer by using audio recorder.

After that, the questionnaire was also distributed to 20 students from class XI-IPS 1 . The questionnaires consisted of ten (10) statements. Meanwhile, in filling out the questionnaire, the students should respond to some statements by placing the checklist $[\sqrt{ }]$ on every answer's column. It was carried out on 15th of January, 2020. After collecting the results of the instruments, the writer [i-[1]analyzed them to correlate with the research questions. The writer used two data analysis techniques to analyze the three research instruments including the conversational analysis and the statistical techniques which were adapted from Dawson (2007, p. 123).

\section{Result and Discussion Result}

After collecting the data from the research instruments, the writer conducted the analysis that was described as follows: 


\section{The teacher's ways in improving the students' ability in writing recount text through collaborative writing on Facebook}

As stated in the first chapter, the first research question in this research was stated in the following question: "How does the teacher improve the students' ability in writing recount text through collaborative writing on Facebook?" In this case, the results of the observation were triangulated with the results of the interview on the first and the second questions to answer the first research question. It was aimed at finding out how the teacher improves the students' ability in writing recount text through collaborative writing on Facebook.

The results of the observation which were correlated with the results of the interview on the first and the second questions showed that the teacher improved the students' ability in writing recount text through collaborative writing on Facebook. In this case, collaborative writing technique on Facebook was used because it could improve the students' motivation and confidence in writing recount text. Besides, they could write recount text collaboratively anywhere and anytime because it could be accessed online. The process of using collaborative writing on Facebook in teaching writing of recount text was implemented in several steps. The first, the teacher reviewed briefly the definition of recount text to be learned by the students before implementing collaborative writing on Facebook.

The second, the teacher discussed briefly about Facebook with the students. The third, the teacher also explained and correlated collaborative writing on Facebook with the students. The fourth, the teacher instructed the students to make small groups of four before teaching writing of recount text through collaborative writing on Facebook. The fifth, the teacher instructed the students to make a recount text based on their own experiences. It was done collaboratively in order to improve the students' interaction. The sixth, the teacher opened and showed a class group on Facebook site to the students. Besides that, he also instructed to post their recount text on Facebook. The seventh, the students in group were allowed to post comments and corrections on other groups' recount texts which have been posted on Facebook group.

The eighth, the teacher and the students discussed about recount texts which have been written and posted by the students on online Facebook group. It was done by giving feedback comments and corrections on other groups' recount texts. In this case, feedback comments and corrections were done by discussing grammatical and mechanical structures of the texts. The ninth, the groups were instructed to revise and edit their own recount text based on the previous feedback comments and corrections from the other groups. After revised and edited their texts, they were instructed to submit and post their final corrections to the teacher's Facebook for assessment and evaluation. The last, the teacher organized a plenary coding session for the students to correct their grammar mistakes on recount texts. Those steps were quite similar with the steps in implementing collaborative writing on Facebook in teaching writing which were proposed by Ahmed (2017, p. 149).

\section{The teacher's perceptions on the use of collaborative writing on Facebook in teaching and learning writing of recount text}

As stated in the first chapter, the second research question in this research was stated in the following question: "How does the teacher perceive the use of collaborative writing on Facebook in teaching and learning writing of recount text?" In this case, the results of the interview on the third, the fourth, and the fifth questions were triangulated with the relevant 
theories in the second chapter to answer the second research question. It was aimed at figuring out the teacher's perceptions on the use of collaborative writing on Facebook in teaching and learning writing of recount text.

In summary, the results of the interview on the third to the fifth questions showed that the use of collaborative writing technique on Facebook helped the teacher in teaching writing of recount text. It was because of saving time and encouraging great opportunities in writing recount text. Besides, it improved the students' ability in writing recount text and increased their academic writing skill because of having unlimited learning time to write and helping each other in composing and revising the results collaboratively. In addition, it was also beneficial for the students be more active, creative, and interactive in writing recount text. Furthermore, it could also encourage students' motivation, attitude, and attention in writing recount text. In addition, it could also reduce students' difficulties in grammar and vocabulary. In line with this, Talib and Cheung (2017, p. 47) argue that "collaborative writing was useful in helping them to improve their grammatical accuracy and vocabulary acquisition."

\section{The students' perceptions on the use of collaborative writing on Facebook in teaching and learning writing of recount text}

As stated in the first chapter, the third research question in this research was stated in the following question: "How do the students perceive the use of collaborative writing on Facebook in teaching and learning writing of recount text?" In this case, the results of the questionnaires were triangulated with the relevant theories in the second chapter to answer the third research question. It was aimed at figuring out the students' perceptions on the use of collaborative writing on Facebook in teaching and learning writing of recount text.

having analyzed the students' responses on the questionnaires by presenting and explaining each question, the writer presented the results into the following figure 4.3 to figure out the students' perceptions on the use of collaborative writing on Facebook in teaching and learning writing of recount text.

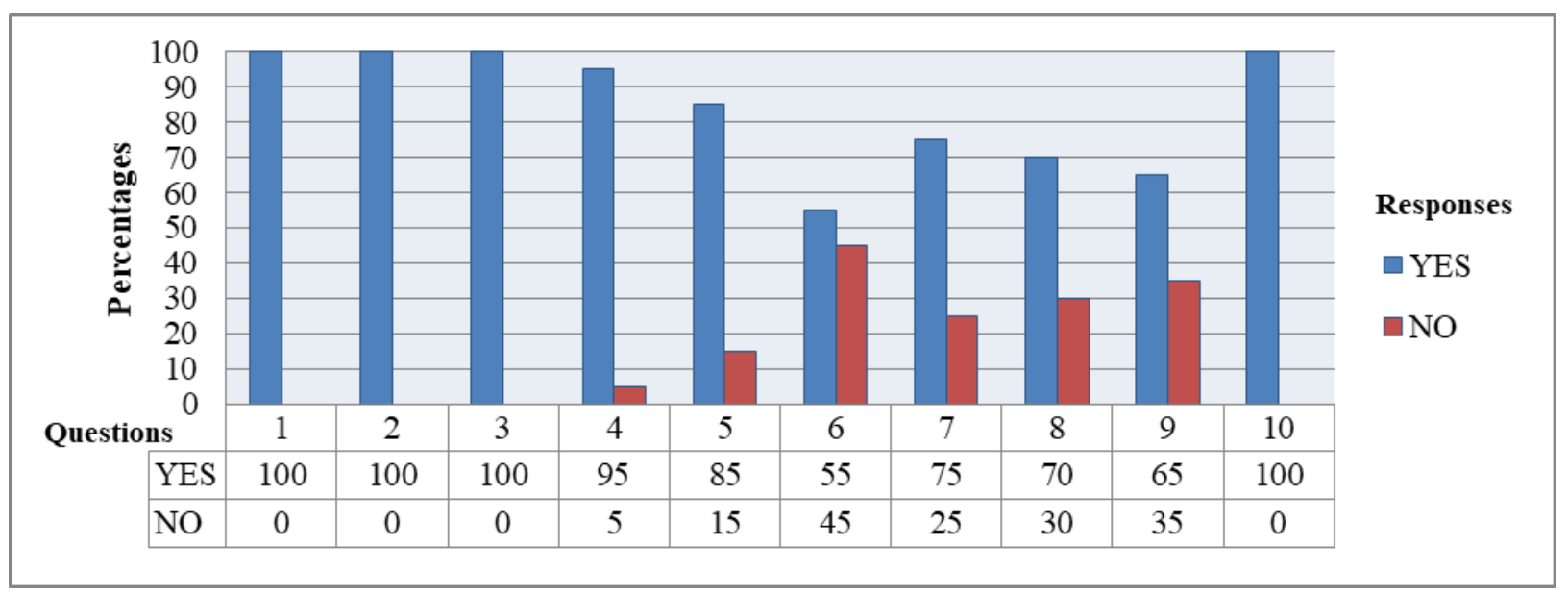

Figure 4.1 The percentages of students' responses on the questionnaires 
Based on the figure 4.1, all students responded that they could write recount text better when they worked collaboratively on Facebook. It was supported by 20 students and the percentage was $100 \%$. Besides, they responded that they could plan, write, and revise recount text better when they worked collaboratively on Facebook. It was supported by 20 students and the percentage was $100 \%$. Meanwhile, they responded that they preferred writing recount texts when they worked collaboratively with friends on Facebook than when they worked alone. It was supported by 20 students and the percentage was $100 \%$.

In this case, they responded that they preferred their teacher to use more group activities / assignments such as writing collaborative texts on Facebook. It was supported by 19 students and the percentage was $95 \%$. In this regard, they responded that collaborative writing on Facebook was useful for their English writing. It was supported by 17 students and the percentage was $85 \%$. Furthermore, they responded that collaborative writing on Facebook has helped them write recount texts faster in English. It was supported by 11 students and the percentage was 55\%. Besides, they responded that collaborative writing on Facebook has helped them to find out how to improve their recount text writing better. It was supported by 15 students and the percentage was $75 \%$.

Meanwhile, they responded that collaborative writing on Facebook has helped them overcome difficulties in vocabulary and grammar in writing recount texts. It was supported by 14 students and the percentage was $70 \%$. Furthermore, they responded that collaborative writing on Facebook helped improve their English writing, especially in writing recount texts. It was supported by 13 students and the percentage was $65 \%$. In addition, they responded that collaborative writing on Facebook has helped them to express themselves in the language of writing recount texts better. It was supported by 20 students and the percentage was $100 \%$.

To conclude, the students perceive positively on the use of collaborative writing on Facebook in teaching and learning writing of recount text. In this case, they could plan, write, and revise recount text better and faster. Therefore, they preferred writing recount text collaboratively and suggested their teacher to use more group activities / assignments by empowering collaborative writing on Facebook. Moreover, it was useful for their writing of recount text and helped them overcome difficulties in vocabulary and grammar. Besides, it improved their English writing, especially in writing recount text and helped them to express themselves in the language of writing recount texts better.

\section{Discussion}

This research focused on improving the students' ability in writing recount text through collaborative writing on Facebook at the tenth grade of a Senior High School in Kawali. The results of the observation had been correlated with the results of the first and the second interview to answer the first research question. The findings could be concluded that the teacher improved the students' ability in writing recount text through collaborative writing on Facebook. The process of using collaborative writing on Facebook in teaching writing of recount text was implemented in ten steps. Those steps were quite similar with the steps in implementing collaborative writing on Facebook in teaching writing which were proposed by Ahmed (2017, p. 149).

The results of the interview on the third to the fifth questions had been analyzed to answer the second research question. The findings could be concluded that the use of collaborative writing technique on Facebook helped the teacher in teaching writing of recount 
text. The results of the questionnaires from the first to the tenth questions had been also analyzed to answer the third research question. The findings could be concluded that the students perceive positively on the use of collaborative writing on Facebook in teaching and learning writing of recount text. In this case, they could plan, write, and revise recount text better and faster.

To support the findings of the present research, some previous studies pertinent to improving the students' ability in writing recount text through collaborative writing on Facebook have been conducted. One of them is a study from Ananthan and Said (2019) entitled "The Effects of Collaborative Writing through Facebook on Pupils' ESL Writing Apprehension." They concluded that there were significant effects of using Facebook in collaborative writing on ESL students' writing apprehension level. The findings of the previous study conducted by Ananthan and Said (2019) also supported the findings of the present research which found that the use of collaborative writing on Facebook improved the students' ability in writing recount text and increased their academic writing skill.

However, there were some differences between this research and the previous study which was initially conducted. The previous study conducted by Ananthan and Said (2019) did not investigate the teacher's ways in improving the students' ability in writing recount text through collaborative writing on Facebook. Furthermore, Ananthan and Said (2019) focused on determining how using Facebook in collaborative writing effects ESL students' apprehension towards writing. However, this research investigated the teacher's ways in improving the students' ability in writing recount text through collaborative writing on Facebook which seem similar with the steps proposed by Ahmed (2017, p. 149).

Furthermore, the study about the use of collaborative writing on Facebook was also conducted by Bailey and Judd (2018) entitled "The Effects of Online Collaborative Writing and TOEIC Writing Test-Preparation on L2 Writing Performance." They concluded that the students increased their writing accuracy on social media platforms like Facebook. The findings of the previous study conducted by Bailey and Judd (2018) also strengthened the findings of the present research which found that the use of collaborative writing on Facebook improved their writing recount text better and faster.

However, there were some differences between this research and the previous study which was initially conducted. The previous study conducted by Bailey and Judd (2018) did not investigate the teacher and the students' perceptions on the use of collaborative writing on Facebook in teaching and learning writing of recount text. Furthermore, Bailey and Judd (2018) focused on analyzing the effects of online collaborative writing and the Test of English for International Communication (TOEIC) writing training on writing performance. Meanwhile, this research investigated the teacher and the students' perceptions on the use of collaborative writing on Facebook in teaching and learning writing of recount text.

Other writers, a study about the use of collaborative writing on Facebook was also conducted by Mahmud and Wong (2018) entitled "Facebook and Collaborative Learning: An Empirical Study on Online Assessment." They concluded that the incorporation of online peer assessment and collaborative learning environment enhance students' interest and motivation. The findings of the previous study conducted by Mahmud and Wong (2018) also acknowledged the findings of the present research which found that the use of collaborative writing on Facebook encouraged students' motivation, attitude, and attention in writing recount text. 
However, the previous study conducted by Mahmud and Wong (2018) did not investigate the teacher's ways in improving the students' ability in writing recount text through collaborative writing on Facebook. Furthermore, Mahmud and Wong (2018) focused on peer assessment's integration for an English Critical and Creative Writing class. However, this research investigated the teacher's ways in improving the students' ability in writing recount text through collaborative writing on Facebook which seem similar with the steps proposed by Ahmed (2017, p. 149).

\section{Conclusions and Suggestions Conclusions}

There are three broad conclusions to answer the research questions. The first conclusion showed that the teacher improved the students' ability in writing recount text through collaborative writing on Facebook. The teacher used ten steps to improve the students' ability in writing recount text through collaborative writing on Facebook. Those steps were quite similar with the steps in implementing collaborative writing on Facebook in teaching writing which were proposed by Ahmed (2017, p. 149).

The second conclusion showed that the use of collaborative writing technique on Facebook was beneficial for the teacher in teaching writing of recount text. The third conclusion showed that the students perceive positively on the use of collaborative writing on Facebook in teaching and learning writing of recount text.

\section{Suggestions}

Regarding the conclusions, the English teachers were suggested to encourage the students to implement collaborative writing on Facebook in teaching writing of recount text. Meanwhile, the students were also suggested to solve problems in learning writing of recount text by implementing collaboration writing technique on Facebook. In addition, the other researchers can use the result of this research in carrying out further studies.

\section{References}

Ahmed, M. (2016). Using Facebook to develop grammar discussion and writing skills in English as a foreign language for university students. Qassim: Sino-US English Teaching, 13(12), 932-952.

Ali, A. (2016). Medical students' use of Facebook for educational purposes. London, Perspect Med Educ, 5(1), 163-169

Al-Rahmi, W. M. (2017). A model of using social media for collaborative learning to enhance learners' performance on learning. Kuala Lumpur: Journal of King Saud University Computer and Information Sciences, 29(1), 526-535.

Al Tai, Y. (2015). The effect of collaboration on Omani students' writing: A comparison between individual, pair and group work. Oman: European Scientific Journal, 1(1) 154-171. 
Al-Tamimi, M. F. (2018). The effect of using Facebook on improving English language writing skills and vocabulary enrichment among University of Jordan sophomore Students. Jordan: Journal of Social Sciences (COES\&RJ-JSS), 7(3), 187-214.

Amasha, M., \& Alkhalaf, S. (2014). The effect of using Facebook markup language (FBML) for designing an e-learning model in higher education. Alrass: International Journal of Research in Computer Science, 4(5), 1-9.

Ananthan, A. S., \& Said, N. E. M. (2019). The effects of collaborative writing through Facebook on pupils' ESL writing apprehension. Selangor: International Journal of New Technology and Research (IJNTR), 5(5), 7-13.

Ataie, F., Shah, A. S., \& Nazir, M. N. M. (2015). Collaborative learning, using Facebook's page and groups. Kuala Lumpur: International Journal of Computer System, 2(2), 4752.

Bailey, D. R., \& Judd, C. (2018). The effects of online collaborative writing and TOEIC writing test-preparation on L2 writing performance. Korea: The Journal of Asia TEFL, 15(12), 383-397.

Behroozizad, S. (2015). An integrated approach to improve the writing performance of the Iranian EFL learners: Scaffolding means and process writing. Maragheh: International Journal of Language Learning and Applied Linguistics World (IJLLALW), 8(1), 112-125.

Beseler, L. M. \& Qi, L. (2014). A Study in Collaborative Writing. Minnesota: International Journal of Bilingual \& Multilingual Teachers of English, 2(1), 15-29.

Bryman, A. (2005). Research methods and organization studies. London: Taylor \& Francis Group.

Dawson, C. (2007). A practical guide to research methods: A user-friendly manual for mastering research techniques and projects (Third edition). Oxford: How To Books Ltd.

Dhillon, B., Herman, H., \& Syafryadin, S. (2020). The Effect of Skimming Method to Improve Students' Ability in Reading Comprehension on Narrative Text.. Linguists : Journal Of Linguistics and Language Teaching, 6(1), 77-88. doi:http://dx.doi.org/10.29300/ling.v6i1.2991

Martina, F., Syafryadin, S., Juwita, S., \& Rakhmanina, L. (2020). The effect of time constraint on student reading comprehension test performance in narrative text. Journal of Languages and Language Teaching, 8(3), 323-329.

Fraenkel, J. R., Wallen, N., \& Hyun, H. (2012). How to design and evaluate research in education (Eighth edition). New York: The McGraw-Hill Companies, Inc. 
Ghufron, M. A., \& Hawa, M. (2015). The effect of collaborative writing technique in teaching argumentative essay writing viewed from the students' creativity. Bojonegoro: LANGUAGE CIRCLE: Journal lof Language and Literature, 10(1), 49-60.

Harmer, J. (2004). How to teach writing. Essex: Person Education Limited.

Hilman, A. (2019). The effectiveness of using Instagram in developing students' descriptive text writing. Ciamis: Journal of Applied Linguistics and Literacy (JALL), 3(1), 31-44.

Ibrahim, S., Saad, S., Tahir, M. N., \& Primsuwan, P. 2(018). Promoting learners' autonomy by using Facebook to enhance students' writing skills. Kedah: Journal of Creative Practices in Language Learning and Teaching (CPLT), 6(1), 56-68.

Jalili, M. H., \& Shahrokhi, M. (2017). The effect of collaborative writing on Iranian EFL learners' L2 writing anxiety and attitudes. Isfahan: Journal of Applied Linguistics and Language Research, 4(2), 203-215.

Knapp, P., \& Watkins. M. (2005). Genre, text, grammar: Technologies for teaching and assessing writing. Sydney: University of New South Wales Press, Ltd.

Kustina, Y., Febriani, R. B., \& Rohayati, D. (2020). Indirect teacher feedback to reduce students' grammatical errors in writing recount text. Ciamis: Journal of Applied Linguistics and Literacy (JALL), 2(2), 125-134.

Lawrence, D., \& Wah, L. K. (2016). Collaborative writing among second language learners using Google docs in a secondary school context. Sabah: International Journal on ELearning Practices (IJELP), 3(1), 63-81.

Li, V. (2016). Social media in English language teaching and learning. Hong Kong: International Journal of Learning and Teaching, 3(2), 148-153.

Mahmud, M. M., \& Wong, S. F. (2018). Facebook and Collaborative Learning: An Empirical Study on Online Assessment. Bandar Sunway: International Journal of Learning and Teaching, 4(2), 107-113.

Manchón, R. M. (2011). Learning-to-write and writing-to-learn in an additional language. Amsterdam: John Benjamins Publishing Company.

Marleni, M. (2020). Enhancing the Students' Writing Skill through Technological Writing Feature of Wridea. Journal of English Education and Teaching, 4(1), 140-153.

Rahmawati, I. N., Syafryadin, S., \& Widiastuti, R. (2019). Teaching Narrative Writing Using Freaky Fables Game: An Experimentation. English Education: Jurnal Tadris Bahasa Inggris, 12(2), 147-155. 
Sembiring, L. T. A. B. (2018). Researching students' interaction in collaborative learning class. Ciamis: Journal of Applied Linguistics and Literacy (JALL), 2(2), 125-134.

Sipayung, K. T. (2016). The implementation of collaborative writing method to improve students' writing of descriptive genre at SMP Negeri 3 Percut Sei Tuan on grade VIII at the academic year 2015/2016. Medan: JURNAL Suluh Pendidikan FKIP-UHN, $3(1), 88-99$.

Sofyan, D., \& Jayanti, F. G. (2019). The Correlation between Reading Self-Efficacy and Reading Comprehension. Journal of English Education and Teaching, 3(1), 1-13.

Sulisworo, D., Rahayu, T., \& Akhsan, R. N. (2016). The students' academic writing skill after implementing blended learning using Facebook. Yogyakarta: Information Technologies and Learning Tools, 56(6), 176-191.

Talib, T., \& Cheung, Y. L. (2017). Collaborative writing in classroom instruction: A synthesis of recent research. Nanyang: The English Teacher, 46(2), 43-57.

Wei, L., \& Moyer, M. G. (2008). The Blackwell guide to research methods in bilingualism and multilingualism. Victoria: Blackwell Publishing Ltd. 